Volume 15 Issue 2 Year: 2018

\title{
Globalization and changing nursing workforce within the framework of flexibility model
}

\author{
Emine Öncü ${ }^{1}$
}

\begin{abstract}
Globalization was developed as a response to the capitalism's great economic crisis in the 1970's. During this period, the social state implementations were abandoned amid increasing competitive conditions, and flexible employment model shaped through neoliberal policies became dominant in the working life. Healthcare industry, which was not very interesting for the capitalist class up until then became another focal point to yield further profits and the 40 years that passed since became an economic industry. Under the competitive free market order, minimized state intervention, privatization and flexibility applications narrowed the gap between public and private, insecure work, increasing obscurity and duration of in working hours, obscurity in job descriptions, outsourcing, performance-based remuneration changed the work life and working conditions of healthcare employees. Nursing should not be considered apart from the system, outside of these applied policies. Therefore, nurses should be aware of these implemented policies and the effects of globalization.
\end{abstract}

Keywords: Globalization; Nursing profession; Global health; Liberal policy; Flexible work.

\section{Introduction}

Globalization is a period that came into our lives in the 70's in the world and 1980's in Turkey, which reflects our passage from a bifocal world to a single focal world following the Cold war with narratives of development and advancement through slogans such as "end of ideologies", "one world" and "global village". Although the end of globalization is in discussion now following the 2007 crisis, it can be observed that the effects of globalization on nursing working life has so far only limitedly assessed.

The purpose of this compilation prepared by searching the literature is to assess globalization throughout the historical process and its impact on health, nursing work environment, labor force and nursing information.

\section{The political economy framework throughout the historical process and globalization}

While creating healthcare policies, the economic structure in the country and the production style shaped on this economic structure become fundamental determiners (Belek, 2009). While the economic system that guides the production relationships in the country comprise the base structure, public institutions such as ideology, religion, morals, politics, art, the state, education, health etc. comprise the upper structure. While the base and upper structure impact and be impacted by each other, these impacts are not bounded by national borders and

${ }^{1}$ Ph.D., Mersin University, Nursing Faculty, Community Health Nursing Department, eeoncu@gmail.com 
Öncü, E. (2018). Globalization and changing nursing workforce within the framework of flexibility model. Journal of Human Sciences, 15(2), 1185-1192. doi:10.14687/jhs.v15i2.4842

are also susceptible to external impact. Therefore, production relationships determine the public health directly and at the same time they also determine how the upper body institution of healthcare services will be organized, what sort of division of work will they be executed through and how they will be financed (Belek, Nalçacı, Onuroğulları, \& Ardıç, 1998; Nalçacı, Hamzaoğlu, \& Özalp, 2006).

Throughout the historical progress, five different types of production relationship can be mentioned: primal communal, slaver, feudal, capitalist and socialist production relationships. Primal communal populations do not yield the excess product to enable the emergence of classes and health is from all to all and for all (Belek, 2009; Belek et al., 1998). Subsequent to this, the first public classification based on slave labor in order to produce more than the population consumes was realized. People with militaristic power, skill and foresight own these surplus products and in the slaver society the cultural development, scientific work and health belongs to the master. While the slave owners confiscate the surplus product in the slaver societies, the slave is left with only what he/she can sustain on. The situation of the serf who works the soil is not entirely different than the slave. Emergence of the proletariat or the labor class who are in fact the serfs liberalized by the feudal landlords to market their labor power in the landlords' textile mills coincide with the years when capitalist production started developing. Capitalism was first seen in England where industrialization began. Capitalism that became the dominant socioeconomical system since the $17^{\text {th }}$ century is still the dominant production style (Belek, 2009; Nalçacı et al., 2006; Belek et al., 1998).

In the capitalist system, there are two societal classes with conflicting interests: the "very large working class" and "capitalist class owning all means of production who are few in numbers". While the capitalist class has the constant purpose of realizing larger profits, they strive to do so through cheaper and fewer workers. But since the ultimate consumer of the produced goods is the waged working class, the capitalist market is a market with limited buyers. As profit margins decline through increasing production and decreasing consumption, capitalism always faces large crises in every 20-25 years and cyclical economic crises ever 5-10 year periods. The crises are tried to be surpassed through production models that are not similar to the previous period. The world tried to surpass the 1929 crisis through social state applications and the 1970 crisis through neoliberal policies and flexible production applications. And the world faced yet another crisis in 2007 (Işıkl1, 2009; Mütevellioğlu \& Ersezer, 2008; Jalee, 1995).

The fundamental ideology of capitalism is liberalism that is being tried since the $18^{\text {th }}$ century. According to the liberalist discipline that argues the survival of the fittest and elimination of the others in human societies, state intervention in economy was a bad thing. Without state intervention, the smartest, the most skillful, the craftiest, the most powerful would prevail (Akalın, 2010; Issıkl1, 2009). Their success is for the good of the society as well. Thus the wealth would accumulate with those who would use it the best and their personal benefit will eventually also bring societal benefit. Since despite liberal policies the capitalist economies stumbled into a very deep depression in 1929, this time liberal theorist Keynes emerged. Keynes assumed an approach that argues abandoning the observatory status of state to save the economic system based on private enterprise. This new point of view green lighted the transition from a liberal state to a social state and enabled the establishment of social state in history following the Second World War. Thanks to Keynes' state centered economic administration model, every person in the countries that adopted the social state model gained employment and were bestowed the rights of education, health, social security through minimum wage guarantee. Interventions of capitalism, which shrank in 1970's because of declining profit margins, in order to overcome the structural crisis also brought new social, economic and political arrangements (Işıklı, 2009; Mütevellioğlu \& Ersezer, 2008).

Globalization is one of the liberal arrangements brought into the agenda by the neoliberal governments led by Reagan of USA and Thatcher in England in 1990s as a new capital accumulation strategy to solve the capitalism's structural crisis in 1970's. Globalization is being 
Öncü, E. (2018). Globalization and changing nursing workforce within the framework of flexibility model. Journal of Human Sciences, 15(2), 1185-1192. doi:10.14687/ihs.v15i2.4842

defined as the "ever increasing mobility of goods, services, labor, technologies and money in the world". In this period, neoliberal policies and competitive free market order with no state intervention came into force, scaling down of the government, privatization and flexibility and therefore the lowering of labor costs became the strategies of globalization. Social state applications that were viewed as obstacles to development and advancement were abandoned (Abbott \& Coenen, 2008; Mütevellioğlu \& Ersezer, 2008).

\section{Reflection of globalization on health outcomes}

The dominant narrative regarding global economic order is that liberal policies will yield economic growth, and the increase in economic gain will seep from top to bottom to provide more income to disadvantaged groups. People who view globalization as such also state that globalization enabled developments in information and technology, the increased competition also increased the goods and services in the market and thus improved living standards (FalkRafael, 2006; Kirk, 2002). But today, despite the changes towards development, inequalities still exist. Still $30 \%$ of 188 countries population experience a multi directional poverty where health, education and living standards are assessed together (UNDP, 2016). In each country, the rich and the powerful live longer and healthier lives. Life expectancy in Canada, Japan and Iceland reach upwards to 82 years where this is below 60 years in the 22 countries in Sub-Saharan Africa (WHO, 2016). In Europe, only 6 out of every 1,000 children die before the age of 5, while this rate is 84/1,000 in Sub-Saharan Africa (United Nations, 2017). Again, 2/3s of all cancer related deaths and $80 \%$ of premature deaths from non-infectious diseases took place in low and middle income countries (WHO, 2013). Although these problems regarding international health stress the ever increasing inequality, these can be solved through technical support and healthcare service. On the other hand, other plights brought by the increasing competition due to globalization such as global warming, consumption trends, decrease in biodiversity, wars and conflicts and the exponential growth of human population is threatening global health and universal life in a non-reversible manner (Falk-Rafael, 2006).

\section{Flexible work practices in nursing}

Globalization and neoliberal policies affect the working life, as working relationships are being reorganized to suit the flexible employment model. These impacts are also reflected in the nursing work life. The development in information technologies and competition introduced by globalization is the source of the new employment style named "flexible working". "Flexible working model" which started to be implemented in the West since 1970's following the abandoning of the Keynesian view became widespread in 1990's through economic and technologic developments and today stands as the dominant production model (Tatlıoğlu, 2012; Mütevellioğlu \& Ersezer, 2008).

The following part of the study discusses the impact of the flexible model on nursing work environment, working conditions and education.

\section{Numerical flexibility}

According to the flexible model that is being applied, the number of the working force is being determined as per the market demand, and the principle to deliver a lot of work through a limited number of workers is being embraced to decrease labor costs. Overtime and excessive working in nursing is observed to increase in the last 10 years. Overtime hours of 10.6 in Japan and 4.8 in England in 2002 increased to 12 in Japan, 18.2 in Iceland, 28 in England, 37 in in USA in 2013/2015 (ICN, 2013/2015). A research conducted in Istanbul, Turkey comprising 18 private hospitals showed that weekly working hours of nurses exceed 70 (Özkan \& Çatıker, 2010). A study conducted by American Nurses Association (ANA) with 4,600 nurses show that a large percentage $(55 \%)$ of nurses work between 41 and 60 hours and $74 \%$ state that they are being affected by excessive working and stress. $56 \%$ of the nurses have daily working shifts over 10 
Öncü, E. (2018). Globalization and changing nursing workforce within the framework of flexibility model. Journal of Human Sciences, 15(2), 1185-1192. doi:10.14687/ihs.v15i2.4842

hours, while 53\% do mandatory/ unplanned overtime each month (ANA, 2011). On the other hand, $2.1 \%$ of the nurses in the USA are unemployed (ICN, 2015).

Another study including 31,627 nurses from 12 European countries indicate that $19 \%$ of them work above 10 hours every day, and though normal daily shifts are below 8 hours a day, one out of 20 nurses in Belgium, Germany, Greece, The Netherlands, Norway, and Sweden work 12 hours and above; overtime is most abundant in England, Ireland and Poland with the highest shortage of nursing workforce, where nurses doing overtime range between $40 \%$ and $50 \%$. According to the researchers assessing the results of the study, the real intent of the employers should be understood and it should be questioned whether the real intent of having less number of employees working longer hours is to decrease expenses or to use the labor force more productively (Griffiths et al., 2014).

\section{Payment flexibility}

In the applied flexibility model, the wages are being paid as per individual performance (Özkan \& Çatıker, 2010). The globalization and increasing competitive pressure in 1990's pushed organizations to think on management efficiencies and focused the attention on performance management. These approaches emerged by the new competitive landscape also put the Ministry of Health in Turkey into action and in 2004 Performance Based Additional Payment System (PBAPS) was put into effect in public hospitals (Çetinkaya, 2016). As per this system, doctors earn additional income in line with their number of performed examinations and interventional procedures. Considering that healthcare services is a team work, the nurses whose work was not being scored were being rated in line with the average point of the institution. While the obtained hasty increase in the supply and demand of healthcare services and comprehensive utilization of advanced healthcare technologies brought concerns on the financial sustainability of the healthcare system, a research showing the impact of PBAPS in different industries indicates that the performance based remuneration applications in hospitals are insufficient in motivating the employees and fulfilling the purpose of providing qualified services (Çetinkaya, 2016; Sülkü, 2011). Another research done in Turkey states that this application brings additional responsibilities to the employees and push them to non-ethical behaviors, and a large percentage of employees (61\%) are not content with the performance based additional remuneration application (Çoban \& Serçe, 2015).

Outsourcing exposes employees to longer terms of unguaranteed working under competition based market conditions while decreasing labor costs. Outsourcing in the public and private healthcare industry in recent years initially began in food, cleaning and security services now expand into medical examination and diagnosis services such as radiology, scanning and laboratories. While the ratio of employees outsourced in the healthcare industry in 2002 was 4.3\% of the total number of healthcare staff, this ratio increased to 26.4\% in 2010 (Etiler, 2015; Özkan \& Çattker, 2010). On the other hand, while it is known that some of the nurses are being outsourced from third party companies, the exact number of outsourced nurses is unknown. In Turkey, in the $1^{\text {st }}$ Step applied in 2010 Family Practice system and the $2^{\text {nd }}$ and $3^{\text {rd }}$ steps, the healthcare workers became contracted employees. Contracted nurses are known to experience work and income insecurity (Özkan, Kan-Öntürk, Himmetoğlu, Artan, \& Güldibi, 2009; Sayan Özkal \& Küçük, 2012).

\section{Time based flexibility}

Working hours- working during the weekend, temporary employment, nighttime employment, part-time employment, increasing working hours- are becoming uncertain. Percentage of part time working registered nurses is $51 \%$ in Denmark, $44.5 \%$ in Australia, 36\% in Ireland, $29.2 \%$ in Canada, $19.2 \%$ in Japan and $15 \%$ in USA Part-time employment brings a more intense working condition in a shorter duration of time, while employees are required to work a 
Öncü, E. (2018). Globalization and changing nursing workforce within the framework of flexibility model. Journal of Human Sciences, 15(2), 1185-1192. doi:10.14687/ihs.v15i2.4842

greater number of years in order to fulfill the required number of working days for retirement (ICN, 2015; Özkan \& Çatıker, 2010).

\section{Functional flexibility}

Job definitions are becoming more flexible and employees can do a variety of work and assume various duties in order to decrease costs. In order to decrease costs, nurses are working instead of doctors, cleaning workers instead of nurses, dental technicians instead of dentists, while in England practitioner nurses are writing prescriptions. In our country, as outsourcing is becoming more prevalent, nurses, midwives etc. may do works outside their profession under cleaning worker staff. Nursing care in a large portion of private hospitals are being provided by persons who did not receive nursing education but instead attended courses (Özkan \& Çatıker, 2010). In Turkey, in private sector, a health officer can be seen on duty in the emergency service, and also $\mathrm{x}$-ray patients when required. While this is something that can only be witnessed in very small hospitals in the public sector, it is observed to be prevalent in the private healthcare institutions. Again, in a state hospital every clinic has its own nurses, while in most of the private hospitals, nurses serve in every clinic. By doing so, in patients in pediatrics clinic to surgery are under the responsibility of the same nurses during night shifts. This functional flexibility also brings numerical flexibility (Etiler, 2015).

Total quality management (TQM) works, which is another subject that will be assessed under functional flexibility, is being implemented as another method to sustain competition. TQM enables the whole process to be kept under control by the employees to prevent the labor force to be alienated from the duty and thus prevent mistakes and also adding meaning to the life workforce, on the other hand keeps the profit targets of capital out of sight (Belek, 2010).

\section{Workplace flexibility}

Spaces that produce healthcare services changed. Doctor's offices were replaced with chain hospitals, pharmacies were replaced with chain pharmacies and private sector work increased rather than public sector. (Özkan \& Çatıker, 2010). Almost half of the nurses in Germany, 34\% in Australia, 26\% in England work in private sector (ICN, 2015). In Turkey, company intensification is picking up pace in private hospital game, and single branch hospitals are being replaced by "healthcare-groups" such as Medical Park, Universal Health Group, Acrbadem, Memorial and Medicana. In Turkey, $82.4 \%$ of the nurses worked in public institutions while $9.7 \%$ worked in private in 2002 , while these figures were $72.8 \%$ and $15.9 \%$ respectively in 2015 (Köse et al., 2015; Özkan \& Çatıker, 2010).).

In recent years, public private partnership (PPP) practices in hospital management have attracted attention. Privatization is an important element of market competition and governments are observed to incentivize private capital. Privatization has both financing and service provision legs: In healthcare financing, there is a transition from national tax based systems to bonus based systems, while there are various privatization implementations in service provision such as PPP as well. Similar to our country, increasing financing and provision of private healthcare services is being observed in Denmark, Iceland, Norway and Sweden since 1980's as patient contribution rates in examination and medicine service is increasing (Øvretveit, 2003). State as a buyer in PPP is purchasing goods, services and production work from private sector through contracts. This application that was pioneered by England and Australia in the world which can be interpreted as "infusing the private into the public" is being applied in various European countries and Japan through different models (Sayan Özkal \& Küçük, 2012). Large public hospitals in Stockholm, capital of Sweden, and a fewer number of public hospitals in Norway and Denmark were transformed into "public owned companies" (Øvretveit, 2003). In Turkey, "Public-Private Partnership" came into discussion in 2005 through an addendum to the Healthcare Services Fundamental Law and PPP is being implemented through "build-rent-transfer" in 30 integrated healthcare campuses in 22 cities (Sayan Özkal \& Küçük, 2012; Taner \& Altıparmak, 2011). As 
Öncü, E. (2018). Globalization and changing nursing workforce within the framework of flexibility model. Journal of Human Sciences, 15(2), 1185-1192. doi:10.14687/ihs.v15i2.4842

project tender values are very high, only a few number of groups with a very strong capital structure in the industry can attend these which is leading to trustification in healthcare (Karasu, 2011).

In our country, hospitals are being grouped as A, B, C, D, E with respect to their medical and financial services, quality, patient and employee safety, education criteria but this situation is disrupting the "access to equal service" principle for those seeking services and "equal pay for equal work" principle for the service providers (Belek, 2009; Özkan et al., 2009).

\section{Globalization and nursing migration}

Marketization of health increases the labor migration of health, capitalist countries support the migration to decrease education and labor force costs. As a result of marketization in public services, healthcare became one of the fastest growing industries. Across the OECD, healthcare and social work force increased by 48 per cent between the years 2000-2014. But still there are talks of insufficient healthcare workforce; it is stated that 40 million new employees will be needed by 2030, most of them in high and medium income countries (United Nations, 2017). The solution, announced by the World Bank and WHO, is accepting migrating healthcare professionals and increasing the number of schools and students. For example, in USA, the number of nurses are to increase $29 \%$ to close the health-workforce gap, and in the meanwhile the nurse unemployment rate of 2.1\% in 2015 (Özkan \& Çatıker, 2010; Özkan \& Hamzaoğlu, 2008; ICN 2015). Healthcare workforce migration is observed to increase since its beginning in 1970's. The countries that immigrate but also experience a healthcare workforce insufficiency remain the same (South-East Asia, and subsequently Africa) (WHO, 2016). Immigrant healthcare professionals usually work in outside of their profession, in more rural, poor and violence-prone locations (Özkan \& Hamzaoğlu, 2008). In Turkey, a law that was passed in 2011 enabled the employment of foreign nurses.

\section{Globalization effects on information and healthcare technologies}

One of the important impacts of globalization is about the usage of information technologies. Developing information technologies enables the information to reach more people and provides information and communication opportunities for patients and caregivers in remote locations. Usage of information technologies is crucial in nursing to decrease the impact of geographical remoteness. But even in developed countries, the scope and development of electronic healthcare registry systems is insufficient. On the other hand, many societies see this open information system as an electronic exploitation tool and a threat to the ideological and social structure (Abbott \& Coenen, 2008).

Today, expensive new healthcare technologies mostly developed in the North creates pressure towards their usage, while a very small portion of these technologies and the staffs to use these technologies are from the less developed South countries. A similar problem persists in medicine where technology is being used intensively. Globally the most produced and distributed medicines are not the most needed but those believed to yield the highest profits (Ritzer, 2011). Although "primary medicine being affordable and accessible by all" is among the Millennium Development Goals, in the developing countries the average prices of primary medicine is 2.5 times of their international price in public institutions and 6.1 times in private institutions (MDG Gap Task Force, 2009). In developed countries, $60 \%$ of medicine expenditure is being covered by public healthcare insurances or through social security systems, the part of public in developing countries is less than $1 / 3$ and most of the payments are either covered by private institutions or paid by the patients (MDG Gap Task Force, 2009). 
Öncü, E. (2018). Globalization and changing nursing workforce within the framework of flexibility model. Journal of Human Sciences, 15(2), 1185-1192. doi:10.14687/ihs.v15i2.4842

\section{Nursing education and globalization}

Globalization also changed the content of the nursing education and the methods of giving the education. Nursing programs in Latin America, China, Turkey and in many other parts of the world were shaped based on the American Program. Reform movements in Europe through the Bologna process brought academic standards in starting the profession, nursing license, masters and doctorate programs in 45 countries. This is a factor that facilitates the migration of nurses from the developing world. Besides this, there are criticism claiming that standardization increases the sameness, and Western modeled nursing being less suitable from the perspective of Islamic or Asian countries (Herdman, 2004; Temel, 2011).

\section{Conclusion}

Healthcare industry, which people are inclined to see and perceive as a neutral area "excluded" from the struggle of classes, is one of the very subjects of the class struggle from its organization to its financing, its education to daily healthcare applications. Nursing should not be thought to be separated from healthcare politics and systems. As social, economic, political, environmental, legal and technological changes both in international and local level change healthcare policies in the country, this change is also affecting the working environment and conditions in nursing as well as its education. Today, the fundamental topics on the sustainability of nursing that interest the nurses, such as the decrease in nursing workforce, immigration, changes in nursing roles are all results of these policies. Therefore, consequently, the nurses should be aware of these implemented policies, and the effects of globalization, liberal policies and the flexible working model on nursing working life should be discussed as much as the impacts on the individual and the public health in every platform.

\section{References}

Abbott, P. A., \& Coenen, A. (2008). Globalization and advances in information and communication technologies: The impact on nursing and health. Nursing Outlook, 56(5). View Article: https://doi.org/10.1016/j.outlook.2008.06.009

Akalın, M. A. (2010). Toplumcu Tip Sovyetter Birliği Deneyimi (1.baskı). İstanbul: Yazılama yayınevi.

American Nurses Association. (2011). ANA Health and Safety Survey 2011. Retrieved from http://www.nursingworld.org/MainMenuCategories/WorkplaceSafety/Healthy-

Nurse/bullyingworkplaceviolence/2011-HealthSafetySurvey.html

Belek, İ. (2010). Esnek Üretim, Derin Sömürü (2. baskı). İstanbul: Yazılama yayınları.

Belek, İ. (2009). Sağhlğm Politik Ekonomisi (3.baskı). İstanbul: Kayhan matbaacıllk.

Belek, İ., Nalçacı, E., Onuroğulları, H., \& Ardıç, F. (1998). Simefsız Toplum Yolunda Türkiye İçin Sağllk Tę̧i (2. bask1). İstanbul: Sorun yayınları.

Çetinkaya, A. Ş. (2016). Performansa dayalı ücretlendïrmenin ücrete bağlı streste farkllılı yaratma düzeyi: Konya sağlık işletmeleri araştırması. Gaæ̧i Üniversitesi İktisadi ve İdari Bilimler Fakülltesi Dergisi, 2, 374-399.

Çoban, S., \& Serçe, H. (2015). Sağlık çalışanlarının performansa dayalı ek ödeme sistemine yönelik düşünce farkll1ıkları ve bu düşüncelerin memnuniyete etkisi: Nevşehir Devlet Hastanesi örneği. Nevsehir Hacı Bektas Veli Üniversitesi Sosyal Bïlimler Enstitïsü Dergisi, 4, 1-16.

Etiler, N. (2015). Neoliberal politikalar ve sağlık emek gücü üzerine etkileri. Mesleki Sağhlk ve Güvenlike Dergisi, (Ekim-Kasım-Aralık), 2-11.

Falk-Rafael, A. (2006). Globalization and global health: Toward nursing praxis in the global community. ANS Adv Nurs Sci, 29(1), 2-14.

Griffiths, P., Dall'Ora, C., Simon, M., Ball, J., Lindqvist, R., Rafferty, A.-M., ... Aiken, L. H. (2014). Nurses' shift length and overtime working in 12 European countries: the association with perceived quality of care and patient safety. Medical Care, 52(11), 975-81. View Article: https://doi.org/10.1097/MLR.0000000000000233 
Öncü, E. (2018). Globalization and changing nursing workforce within the framework of flexibility model. Journal of Human Sciences, 15(2), 1185-1192. doi:10.14687/ihs.v15i2.4842

Herdman, A. E. (2004). Globalization, internationalization and nursing. Nursing and Health Sciences, 6, $237-238$.

ICN. (2015). Nursing Workforce Profile 2015. Retrieved from http://www.icn.ch/images/stories/documents/pillars/sew/DATASHEET_SUMMARY_N URSING_PROFILE_WFF_2015.pdf

Işıklı, A. (2009). Yeni Ortaçăg (2.baskı). Ankara: İmge kitabevi yayınları.

Jalee, P. (1995). Kapitalizm Nasil İsler? (2. baskı). İstanbul: Belge yayınları.

Karasu, K. (2011). Sağlık hizmetlerinin örgütlenmesinde kamu-özel ortaklı̆̆1. Ankara Üniversitesi SBF Dergisi, (3), 217-262.

Kirk, M. (2002). The impact of globalization and environmental change on health: challenges for nurse education. Nurse Education Today, 22(1), 60-71-75. View Article: https://doi.org/10.1054/nedt.2001.0720

Köse, M. R., Başara, B. B., Güler, C., Soytutan, İ., Aygün, A., Özdemir, T. A., ... Yentür, G. K. (2015). Sağlıkta insan kaynakları. In B. Başara, C. Güler, İ. Soytutan, A. Aygün, \& T. A. Özdemir (Eds.), T.C. Sağhlk Bakanlĭg Sağhk İstatistikleri Yulluğ 2015 (pp. 181-207). Ankara: Sistem Ofset Basım Yayın San. ve Tic. Ltd. Şti.

MDG Gap Task Force. (2009). Strengthening the Global Partnership for Development in a Time of Crisis. United Nations. Retrieved from http://www.un.org/millenniumgoals/pdf/MDG_Gap_ Task_Force_Report_2009.pdf

Mütevellioğlu, N., \& Ersezer, D. (2008). Küreselleşme ve sosyal devlet. In Küreselleşme Demokratikleşme ve Türkije Uluslararası Sempozyumu Bildiri Kitabı (pp. 160-173). Antalya: Akdeniz Üniversitesi İ̈BF.

Nalçacı, E., Hamzaoğlu, O., \& Özalp, E. (2006). Eleştirel Sağhle Sosyolojisi Söəliügü (1. baskı). İstanbul: Kayhan matbaacilik.

Nations, U. (2017). The Sustainable Development Goals Report. United Nations. https://doi.org/10.18356/3405d09f-en

Øvretveit, J. (2003). Nordic privatization and private healthcare. International Journal of Health Planning and Management, 18(3), 233-246. https://doi.org/10.1002/hpm.712

Özkan, Ö., \& Çatıker, A. (2010). Sağllk Sektöründe Esnek Üretim ve Sağlık Emek Gücüne Etkileri. In Kolektif (Ed.), Almanak 2009 analiz̨leri (1. bask1, pp. 477-500). İstanbul: Sosyal Araştırmalar Vakfi.

Özkan, Ö., \& Hamzaoğlu, O. (2008). Uluslararası emek göçü: Ne, nasıl, neden?, Toplum ve Hekim, 23(3), 179-183.

Özkan, Ö., Kan-Öntürk, Z., Himmetoğlu, R., Artan, A., \& Güldibi, Ö. (2009). Iş güvencesiżlï̆i ve sağlik durumlari ile ilişskïsi. Mesleki Sağhlk ve Güvenlik Dergisi, (Temmuz-Ağustos-Eylül), 42-48.

Ritzer, G. (2011). Küresel Dünya. İstanbul: Ayrıntı yayınları.

Sayan Özkal, İ., \& Küçük, A. (2012). Türkiye'de kamu personeli istihdamında dönüşüm: Sağlık Bakanlı̆̆ örneği. Ankara Üniversitesi SBF Dergisi, 67(1), 171-203.

Sülkü, S. N. (2011). Performansa dayalı ek ödeme sisteminin kamu hastanelerinin verimliliği üzerine etkileri. Maliye Dergisi, 160, 242-268.

Taner, Ş., \& Altıparmak, S. (2011). Sağlıkta kamu- özel ortaklığı. Toplum ve Hekim, 26(4), 308-320.

Tatlıoğlu, E. (2012). Güvencelï esneklik çerçevesinde esnek çalışmanın uygulanabilirllĭgi. Electronic Journal of Vocational Colleges, (Aralik), 69-84.

Temel, A. (2011). Küreselleşme ve hemşirelik eğitiminde uluslararasılaşma. DEUHYO ED, 4(3), 144 150.

United Nations Development Programme. (2016). Human Development Report 2016. United Nations Development Programme. View Article: https://doi.org/eISBN: 978-92-1-060036-1

WHO. (2013). Global action plan for the prevention and control of noncommunicable diseases 20132020. World Health Organization, 102. https://doi.org/978 9241506236

WHO. (2016). Working for health and growth: investing in the health workforce. Report of the High-Level Commission on Health Employment and Economic Growth. https://doi.org/10.5117/9789089642530 